\title{
An analysis of spousal competence and non-compellability in terms of section 198 of the Criminal Procedure Act
}

\author{
Melissa Lazarus \\ LLB(WITS) LLM (UKZN) Admitted Attorney of the High Court of South Africa, \\ Ad Hoc Lecturer, University of KwaZulu-Natal \\ Dr Franaaz Khan \\ LLB(UKZN) LLM(UKZN) PhD(UKZN) Senior Lecturer, Department of Private Law, \\ University of Johannesburg
}

\begin{abstract}
SUMMARY
Marital privilege is founded on the biblical principles of the union between man and wife. Thus wives were not competent or compellable witnesses against their husbands. Over the years the privilege developed in English common law. South Africa codified the privilege through Section 198 of the Criminal Procedure Act 51 of 1977 which states that spouses cannot be compelled to testify against each other unless the crime for which the accused spouse is charged appears in the categories listed in Section 195 of the Act. There are many criticisms against affording a privilege to a particular class of persons - notably that the non-compellability exception given to spouses is unconstitutional as it violates the right to equality in terms of section 9 of the Constitution. Recent media coverage at the Zondo Commission highlighted this conundrum when the ex-minister's spouse was asked to testify. This article examines the merits of the unconstitutionality argument and concludes that spousal noncompellability fails to withstand the test against unfair discrimination on the basis of marital privilege. Finally, recommendations are proposed in this regard which examine the nature and evolution of spousal competence and non-compellability in South African law.
\end{abstract}

\section{Introduction}

Marital privilege or the non-compellability exception afforded to spouses finds expression in the ambit of South African common law and in section 198 of the Criminal Procedure Act (hereinafter the CPA). ${ }^{1}$ According to the principles that underlie the privilege, a spouse, although a competent witness, is not compellable unless the crime falls within a specific category. ${ }^{2}$ Spouses therefore are the only category of witnesses

Criminal Procedure Act 51 of 1977.

S 195(1)(a)-(i). Offences committed against the person of either of the spouses or of a child of either of them. Included are the offences of bigamy, incest and abduction, and certain offences in terms of the Child Care Act 74 of 1983, the Maintenance Act 99 of 1998, and the Sexual Offences Act 23 of 1957 . 
who are afforded a privilege that permits them to refuse to disclose to the court evidence that is both admissible and highly relevant in criminal proceedings.

This aspect of spousal non-compellability in South African law was recently highlighted during Judicial Commission of inquiry into state capture otherwise known as the Zondo Commission ${ }^{3}$ when the ExMinister of Finance Malusi Gigabas' legal representatives attempted to utilise marital privilege to prevent his estranged wife from testifying about communications shared between them during the course of their marriage. Despite submissions made at the commission spousal privilege cannot be invoked by Malusi Gigaba because the privilege is vested in the witness spouse and such spouse is the only the holder of the privilege. In addition, spousal privilege applies to criminal proceedings only and the commission is an inquiry. The commission does not mimick proceedings in a criminal court. The above arguments therefore do not represent the proper application of spousal privilege in South African law. There is no doubt however that had the legal representatives of Malusi Gigaba persisted in furtherance of their argument this would have been an interesting test case in respect of a possible extension of the scope of spousal privilege beyond criminal courts to include inquiries and other related proceedings. ${ }^{4}$ An analysis of the arguments presented to the commission in respect of spousal privilege is a startling revelation as to how little is known about this aspect of South African law by present day legal practitioners warranting the need for more scholarly research to be conducted.

In line with the general principles of evidence, as it relates to competence and compellability, Cowen and Carter $^{5}$ provide the following explanation:

"A competent witness is a person whom the law allows a party to ask, but not compel, to give evidence and a compellable witness is a person whom the law allows a party to compel to give evidence. There are certain questions that a witness may refuse to answer if he so wishes. He is said to be privileged in respect of those questions".

While it may be argued that privilege is necessitated by the need to offer protection to certain categories of persons, a right or a public interest ${ }^{6}-$ the point of contention arises when the existence of such a privilege impacts negatively on the court's fact finding function, in that it confers

3 Judicial Commission of inquiry into allegations of state capture is a public inquiry launched by the South African government of Jacob Zuma in January 2018 to investigate allegations of state capture, fraud and corruption in the public sector and organs of state.

4 See https://www.news24.com/news24/analysis/omphemetse-sibanda-mari tal-privilege-and-nomachule-mngomas-state-capture-testimony-20210429 (accessed on 2021-05-01).

5 Cowen and Carter Essays on the law of evidence (1956) 220.

6 Cowen and Carter 221. 
a benefit to a particular group of persons to the exclusion of others. ${ }^{7}$ Arguably it does not take into account factors such as: the current modern definitions of relationships that fall outside the confines of a legal marriage; public policy that demands that a court of law has access to all the relevant evidence to ensure that those who are guilty of a crime are convicted; and perhaps most importantly, the constitutional right to equality. ${ }^{8}$

The consequence has been that the justification of this archaic concept, once firmly embedded within criminal procedure, has recently become increasingly difficult to uphold. Some commentators argue that a continuance of the privilege would be a perpetuation of unfair discrimination. ${ }^{9}$ These rights are enshrined in the Constitution and any 'law or conduct' that is in violation should be disregarded. ${ }^{10}$ The crux of these arguments is that the privilege does not extend to couples who are cohabitants and life partners, and fails to consider relationships that do not conform to the conventional notion of a legal marriage. ${ }^{11}$ The counter-argument is that a spouse also enjoys the right to privacy, which will be undermined should the privilege be removed from South African law. ${ }^{12}$

The questions to be considered in light of the above arguments are therefore, whether the right to marital privilege amounts to unfair discrimination and by its continuance in our law does it perpetuate the privilege outweighing the right to equality thereby proving that the interest in protecting the marital union is more relevant than the interests of justice.

\section{Brief overview of the history of marital privilege}

Marital communications are protected within the law. Evidence of this can be found first, as opposed to any other evidence, in section 3 of the Evidence Amendment Act of 1853. This section provided that:

"No husband shall be compellable to disclose any communication made to him by his wife during the marriage, and no wife shall be compellable to disclose any communication made to her by her husband during the marriage". 13

7 Naude "Spousal competence and compellability to testify: A reconsideration" 2004 South African Journal of Criminal Justice 325-346.

8 Delano, "Section 198 of the criminal Procedure Act: Marital privilege or unfair discrimination on the ground of marital status"? 2017 De Rebus.

$9 \quad$ Naude 329.

10 S 2 Constitution of the Republic of South Africa, 1996.

11 Naude 333.

12 Naude 329

13 S 3 Evidence Amendment Act of 1853. 
The origins of this theory date back to the Bible and have continued through to medieval ecclesiastical law. ${ }^{14}$ According to the prevailing views of the day and in allegiance with spiritual norms and customs, spouses were deemed to be a singular entity that was spiritually ordained. ${ }^{15}$ Husbands and wives were therefore regarded as one. ${ }^{16}$ This formed the basic premise of the common law and reinforced the patriarchal notion that underpinned the values of society - that a husband was the only legally recognised person in the marital union, and therefore marital privilege would practically serve only to protect a husband who was charged with an offence: ${ }^{17}$ It is this theory that formed the basis of marital privilege that persisted for centuries. ${ }^{8}$ The theory started to erode as wives began to emerge with their own separate legal identity that allowed them rights in property and to enter into contractual relationships. As early as 1933 American courts regarded wives as competent witnesses in defence of their husbands but not against them. ${ }^{19}$

\section{Legal framework in South Africa}

The most compelling reason for a reconsideration of marital privilege can be found in the Constitution. In determining whether marital privilege violates the Constitution one must consider section $39(1),{ }^{20}$ which states:

"When interpreting the Bill of Rights, a court, tribunal or forum (a) must promote the values that underlie an open and democratic society based on human dignity, equality and freedom; (b).....(c) may consider foreign law".

To determine whether section 198 of the $\mathrm{CPA}^{21}$ violates the right to equality, section 9 of the Constitution ${ }^{22}$ must be examined. The fact that the privilege only recognises relationships that are valid in law perpetuates unfair discrimination upon those that have sought to be in

14 Lusty "Is there a common law privilege against spouse incrimination?" 2004 The University of New South Wales Journal 1-9.

15 Barton, The competence and compellability of spouses to give evidence in criminal proceedings and the confidentiality of marital communications (LLM dissertation 1977 UNISA).

16 Lusty 3.

17 Lusty 7.

18 Lusty 8.

19 Naude 328.

20 S 39 Constitution of the Republic of South Africa, 1996.

21 Criminal Procedure Act 51 of 1977.

22 S 9 (the 'equality clause', as it is known) of the Bill of Rights states:

(1) Everyone is equal before the law and has the right to equal protection and benefit of the law.

(2) Equality includes the full and equal enjoyment of all rights and freedoms. To promote the achievement of equality, legislative and other measures designed to protect or advance persons, or categories of persons, disadvantaged by unfair discrimination may be taken.

(3) The state may not unfairly discriminate directly or indirectly against anyone on one or more grounds, including race, gender, sex, pregnancy, marital status, ethnic or social origin, colour, sexual orientation, age, disability, religion, conscience, belief, culture, language and birth. 
relationships that are not or cannot be valid in law. ${ }^{23}$ Marital status is a specified ground in section 9(3) of the Constitution ${ }^{24}$ - expounding that one may not be discriminated against on this basis.

In Harksen $v$ Lane $^{25}$ the Constitutional Court set out the stages of an inquiry that need to be undertaken to determine whether the right to equality has been violated and is as follows: ${ }^{26}$

“1 Does the relevant provision differentiate between people or categories of people? If it does, does the differentiation bear a rational connection to a legitimate government purpose"? If it does not, then there is a violation of section 9(1). Even if there is such a connection, it might still amount to discrimination in terms of section 9(3) or (4). ${ }^{27}$

2 Does the differentiation amount to unfair discrimination?

3 This requires a two-stage enquiry:

i First, does the differentiation amount to 'discrimination'? If the discrimination is on a specific ground, then it will have been established. If it is not on a specific ground, then whether or not there is discrimination will depend upon whether, objectively, the ground is based on attributes and characteristics which have the potential to impair the fundamental human dignity of persons as human beings or to affect them adversely in a comparably serious manner. ${ }^{28}$

ii If the differentiation amounts to 'discrimination', does it amount to 'unfair discrimination'? If it has been found to have been on a specific ground, then unfairness will be presumed. If it has been on an unspecified ground, unfairness will have to be established by the complainant. The test of unfairness focuses primarily on the impact of the discrimination on the complainant and others in a similar situation. If this stage of the inquiry finds the differentiation not to be unfair, there will be no violation of subsections (3) and (4).

iii The second stage is to determine if the provision can be justified under the limitation clause".

In terms of the first stage of the enquiry, the provisions of section 198 of the $\mathrm{CPA}^{29}$ make a distinction between married persons and unmarried persons. It is argued, however, that such a differentiation is justified as a rational government objective, and as a result thereof, is not necessarily a violation of section 9(1) of the Constitution. ${ }^{30}$

On application of the second stage of enquiry, the differentiation on the basis of marital status does amount to discrimination. Furthermore,

(4) No person may unfairly discriminate directly or indirectly against anyone on one or more grounds in terms of subsection (3)

(5) Discrimination on one or more of the grounds listed in subsection (3) is unfair unless it is established that the discrimination is fair.

23 Naude 333

24 Constitution of the Republic of South Africa, 1996.

25 Harksen $v$ Lane 1998 (1) SA 300 (CC) para 54.

26 Harksen $v$ Lane 1998 (1) SA 300 (CC) para 54.

27 Harksen $v$ Lane 1998 (1) SA 300 (CC) para 54 and 55.

28 Harksen $v$ Lane 1998 (1) SA 300 (CC) para 54 and 55.

29 Criminal Procedure Act 51 of 1977.

30 Naude 339. 
the fact that marital status is included as a specified ground in terms of section 9(3) of the Constitution means that unfairness is presumed and a prima facie violation of section 9(3) has indeed occurred. ${ }^{31}$ However, discrimination is not automatically deemed to be unfair. ${ }^{32}$ In Harksen $v$ Lane $^{33}$ the court stated that in deciding this issue, the impact that such discrimination had on the victim must be considered by taking into account several factors that should be assessed objectively in respect of its cumulative effect. National Coalition for Gay and Lesbian Equality $v$ Minister of Home Affairs ${ }^{34}$ dealt with unfair discrimination based on marital status. In this case, the Constitutional Court held that the provisions of the Aliens Control Act, ${ }^{35}$ which granted spouses of South African citizens a right to an immigration permit amounted to unfair discrimination on the basis of marital status. The provisions of the Aliens Control Act, much like section 198 of the CPA, differentiated between married persons and those that were not married - in that it granted a benefit to spouses that was not available to the unmarried category of persons, which included life partners and co-habitants. The Constitutional Court also highlighted that the manner in which the protection of the traditional marital regime is carried out, must not unjustifiably limit the constitutional rights of life partners in same sex relationships. ${ }^{36}$ There seems to be no rational connection between the justification for the existence of marital privilege, which is to ensure the marital relationship is protected, and the exclusion of life partners from invoking the protection of the privilege.

The third and final stage of the enquiry deals in terms of section 36 of the Constitution. ${ }^{37}$ If the limitation cannot be justified, then the provisions of section 198 should be declared unconstitutional.

In addition to protecting the right to equality, the Constitution also recognises that spouses, like other categories of witnesses, are deserving of the right to privacy. ${ }^{38}$ It may be argued that such a right may be limited by section 36 of the Constitution. ${ }^{39}$ However, marital communications are regarded as privileged, and section 14 (d) of the Constitution provides that every person has a right against the infringement with whether section 198 of the CPA is a justifiable limitation of his or her private communications. Therefore, the question that arises - is by affording married persons a separate privilege from

$31 \quad$ Naude 339.

32 Naude (above) 339.

33 Harksen $v$ Lane 1998 (1) SA 300 (CC) para 51.

34 National Coalition for Gay and Lesbian Equality $v$ Minister of Home Affairs (CCT10/99) [1999] ZACC 17; 2000 (2) SA 1; 2000 (1) BCLR 39 (2 December 1999) para 40.

35 Alien Control Act 96 of 1991.

36 National Coalition for Gay and Lesbian Equality $v$ Minister of Home Affairs (CCT10/99) [1999] ZACC 17; 2000 (2) SA 1; 2000 (1) BCLR 39 (2 December 1999) para 44.

37 S 36 of the Republic of South Africa, 1996.

38 S 14 Constitution of the Republic of South Africa, 1996.

39 Naude 331. 
testifying, is South African law dictating that the right to privacy supersedes the right to equality?

\section{An overview of the Criminal Procedure Act 51 of 1977}

The current rules governing marital privilege in South Africa are contained in sections 195 to 199 of the CPA. The provisions of section 196(1) render the spouse a competent but non-compellable witness for the defence. According to section 198 of the CPA, a spouse may claim marital privilege and refuse to disclose any communication made during the subsistence of the marriage. An exception can be found in a category of offences contained in section 195 of the CPA, in which a spouse becomes compellable in respect of any of the offences listed under this section.

The holder of the privilege remains the testifying spouse and the accused spouse cannot prevent such communication from being disclosed. ${ }^{40}$ This appears to be a diversion from the general principles attached to other privileges. The notable difference is that in all other privileges, the person for whom the benefit exists is the holder of the privilege, stemming from the fact that it is that person's communication that deserves some sort of protection. ${ }^{41}$ As a result of the testifying spouse being afforded the right of holder, of the privilege, there is no protection afforded to the accused spouse, as he or she has no ability to control whether the communication is divulged and to what extent because no consent is required from the accused spouse. ${ }^{42}$

Section 199 of the CPA provides that a testifying spouse may decline to respond to a question if the accused spouse would not have been compelled to answer that same question. ${ }^{43}$ However, the choice remains with the testifying spouse who may still decide to testify - leaving the accused spouse who made the communication susceptible to the communication being revealed by the testifying spouse. Further, a third person that hears or intercepts the communication cannot be prevented from disclosing it. This suggests that the purpose of the privilege therefore is not concerned with the protection of the spouse, but rather the marital relationship. ${ }^{44}$

As alluded to in the previous paragraph, if the main purpose of the privilege is the protection of the marital relationship, and not the accused spouse, then it is interesting that the privilege persists after divorce. The extension of the privilege after divorce is therefore illogical if the

40 Naude 330.

41 Naude 331.

42 Naude 331.

43 Also S 199 of the Act and s 12 of the Civil Proceedings Evidence Act 25 of 1965.

44 Naude 327 
relationship has been terminated, because any disclosure once the marital union has ended will not cause any harm to the marriage or threaten the way the ex-spouses continue to exchange confidences with each other. ${ }^{45}$ The privilege only extends to communications made during the subsistence of the marriage, and widows and widowers remain excluded. ${ }^{46}$ It is submitted, in support of the view advanced by Naude, ${ }^{47}$ that the privilege should only be afforded with consideration as to the marital status at the time the witness is required to testify and not when the communication was made.

Marital privilege is intriguing and has piqued the writer's interest. It reflects a modern debate on whether society's interest in protecting the sanctity of marriage should outweigh its interest in ensuring that the court can arrive at a proper judgment by placing all the relevant facts before it - particularly the testimony of spouses, which may be highly relevant and yet would otherwise be protected by the privilege. The justification for the continued existence of the privilege remains that should a spouse be compelled to testify against the accused spouse, it would place undue stress and strain on the relationship and could ultimately lead to a breakdown of the marriage. It is argued, however, that this justification may not hold much weight against the effect and outcome of the privilege, which continues to perpetuate a violation of the Constitution through unfair discrimination and inequality on the basis of marital status. These points of criticism coupled with the fact that the privilege places the importance of preserving a marital union over the interests of the court having all the evidence before it, is certainly cause for further inspection into the law governing marital privilege.

South Africa has adopted the same principles as the English in entrenching marital privilege in our law. ${ }^{48}$ Thus, we have inherited the same criticism as our English counterparts that the privilege is outdated and excludes the modern definitions of relationships, which currently are varied and far-reaching. Marital privilege has moved away from a reflection of divine law from which it originated, and instead is seen to reflect an antiquated notion that excludes the realities of the modern day. The law reform commissioners in England reaffirmed this when it was recommended that the privilege in civil proceedings be abolished stating that "it is unrealistic to suppose that candour of communication between husband and wife is influenced today by the statutory provisions'. ${ }^{49}$

45 Naude 331

46 S 198(2) of the Act and s 10(2) of the Civil Proceedings Evidence Act 25 of 1965. The privilege applies even if the communication was not made in confidence - as long as it was made while the spouses were still married; van Niekerk, van der Merwe and van Wyk, "Privilegies in die bewysreg", (1984) 192

47 Naude 331.

48 Barton 78.

49 Law Reform Commission, Privilege in Civil Proceedings, Report No 16 (1967) 7. 
It would appear that the main objective of marital privilege, and particularly the creation of a category of offences in terms of section 195 of the CPA, is that the marriage would remain protected. ${ }^{50}$ The fact that the spouse is compelled to testify in terms of these offences means that he or she would be less susceptible to harm from the accused, as the testifying spouse is giving evidence because he or she is being forced to testify and not of their own volition. ${ }^{51}$ However, this argument does not hold much weight, in that the offences covered by section 195 of the CPA could, in any event, lead to the destruction of the marriage - whether the wife is compelled to testify or not, as most of the offences affect the marriage directly or indirectly as they may relate to the spouse or their children. ${ }^{52}$ Thus the existence of a category of offences is of no specific relevance. ${ }^{53}$ Therefore, it is argued that there is no reason why the spouse should not be subjected to the same rules as any other competent witness, and be compellable for all matters - and not just those subject to the categories as per section 195 of the CPA. ${ }^{54}$

The second reason for the creation of a category of compellable offences, is that it would serve the public interest not to allow the accused to escape liability on the basis of spousal non-compellability. ${ }^{55}$ It would certainly be difficult to justify why certain crimes were not being prosecuted on the basis of non-compellability of spouses, and therefore it would appear that in an attempt to alleviate the public outcry, the legislators decided that for certain offences spouses would be made compellable. In ensuring that there are certain crimes that will not be subject to spousal non-compellability, the legislators are successful in purporting that justice is being metered out in ensuring that the testifying spouse is forced to divulge evidence in respect of those listed offences under S 195 of the CPA. In theory this may appear to be the case - but in practice it is highly debatable.

The inclusion of a list of offences that are exempted from spousal noncompellability appears to have been a small attempt to reform marital privilege in South Africa. While noteworthy, the problems associated with such a list deserve consideration.

The New Zealand Law Commission ${ }^{56}$ paid particular attention to the difficulties encountered with such a list and the operation of the spousal non-compellability privilege in its law, and as a result sought to abrogate the privilege in its entirety from the common law through the release of a Draft Evidence Code. ${ }^{57}$ Although the Draft Evidence Code is yet to be adopted by parliament, the New Zealand Law Commission's comment in

50 Naude 328

51 Naude 329

52 Naude 332

53 Schwikkard and van der Merwe Principles of evidence (2002) 398.

54 Naude 334

55 Naude 332

56 The New Zealand Law Commission, Evidence, Report No 55 (1999) 78.

57 S 61(4)(b) Draft Evidence Code 1999. 
relation to a list of category of offences for which spouses are compellable witnesses, is noteworthy. It stated that:

"These lists of specified offences require decisions by law-makers on
competing public interests that are too broad, and too reliant on intuition
rather than information on actual costs. The evolution of such lists in other
jurisdictions has also shown that over time arbitrary distinctions develop.
They create the potential for complex procedural problems at trials which
involve several charges, not all of which involve listed offences. These
problems are exacerbated if there is more than one accused" ${ }^{58}$

Section 195 of the CPA is no exception to the above and appears to be plagued with its own set of problems. First, the list fails to incorporate many serious offences such as murder. ${ }^{59}$ The list appears to place importance on familial relationships over other persons, and thus a spouse can be compelled to testify about the abuse or assault of their own child - but not about the abuse or assault of somebody else's child.

An additional problem is that our courts have restrictively interpreted the term 'offence against the person', 60 which generally is taken to mean the crime of assault. ${ }^{61}$ The question remains as to whether this may be in line with the original purpose of the legislature. Du Toit ${ }^{62}$ suggests there appears to be no reason why this provision should not include other crimes, particularly those that infringe personality rights such as crimen injuria. This certainly exposes the interpretational difficulties encountered with section 195.

The term 'spouse' under section 195 includes divorced persons provided that the testifying spouse is required to give evidence pertaining to events during the subsistence of the marriage. This was decided in $S v$ Taylor $^{63}$ when the court stated that the words 'wife or husband' in sections 195 and 196 of the CPA, include divorced persons when required to give evidence regarding events during the marriage.

A further problem encountered is when an accused is faced with numerous charges and a testifying spouse is a compellable witness for some but not all of these charges. ${ }^{64}$ It has been proposed that the situation could be alleviated by trying the compellable offences separately from the non-compellable offences. ${ }^{65}$ This, however, may not be practical where the material facts in dispute are inter-related to the other offences, as well as when one considers the costs and time delays that may occur in the separation of these trials due to noncompellability. 66

58 The New Zealand Law Commission, Evidence, Report No 55 (1994) 103.

59 Naude 332.

60 S195(1)(a) Criminal Procedure Act 51 of 1977.

61 Du Toit Commentary on the Criminal Procedure Act (2016) 456.

62 Du Toit 457.

63 S v Taylor 1991 (2) SACR 72 (C) para E.

64 Naude 332.

65 Naude 332

66 Naude 332 
It is quite apparent that the provisions governing spousal noncompellability discriminate on the basis of marital status and can no longer be sustained in this post constitutional era. Amidst the right to equality is the test in terms of section 36 of the Constitution which sets out the test to determine whether there is a justification for limiting the right to equality. The need to afford spouses a privilege to not testify against an accused spouse over other persons in other relationships, which for all intents and purposes amount to a marital relationship, is not a justifiable limitation of the right to equality. While it may be argued that marital privilege remains an important part of our criminal justice system - the question that must be asked is at what expense? It is a privilege that is not absolute, as it is an obstruction of the truth-seeking process. The dilatory tactics adopted by the legislators in not giving the problems associated with the privilege adequate attention, have resulted in an abandonment of the legislatures obligation to uphold the right to equality. While the future of marital privilege remains to be seen- if the Constitution is to be taken seriously, it is a matter that must be given immediate consideration.

\section{An analysis between American and South African law}

Both jurisdictions have recognised the need to afford marital communications a privilege to ensure the protection of a marital relationship, and are at one with each other in this regard. ${ }^{67}$

There is divergence, however, when it comes to the location of the privilege. In American law it is the spouse who makes the communication that is protected, and in South African law the privilege is afforded to the spouse to whom the communication is made. It is proposed in support of Barton's view that the holder of the privilege in South African law is misplaced. ${ }^{68}$ The spouse who made the communication has no control over what evidence the testifying spouse may divulge. The spouse who has made the communication has taken the other spouse into their confidence, and that spouse should therefore have the power to prevent the confidentiality from being breached. ${ }^{69}$ It creates an anomalous situation, as pointed out by Barton ${ }^{70}$ - where the spouse who has not relied on the marital confidence at all, but simply receives the communication, is entitled to breach it. ${ }^{71}$

The other notable difference between American and South African law, as indicated in the preceding paragraphs, is that South African legislation affords the privilege to 'any communication' - as opposed to

67 Barton 45

68 Barton 45

69 Barton 45

70 Barton 45

71 Barton 45. 
American law in which only 'confidential communications' are protected. $^{72}$ Even in states where the American legislation makes reference to 'any communication', the court has taken a restrictive approach, applying it only to communications made in confidence. ${ }^{73}$

It cannot be disputed that American and South African law are at one with each other in respect of the policy justification for the existence of the privilege. In American law, this justification will never change, as society upholds the protection of marital communications as being sacrosanct. Although this remains the current position in South Africa, the future remains questionable. There are some notable divergences in the principles governing the operation of the privilege in these two countries. It is submitted that it is in the divergent roots of American law that South Africa can detect prominent and valuable resources that serve as starting points to investigate the amendment of the current laws pertaining to marital privilege, so bringing it in line with the Constitution.

\section{Conclusion and recommendations}

The mixed views that marital privilege has garnered over the years are best described by Wigmore ${ }^{74}$ in the following quotation.

“... The fantastic spectacle of a fundamental rule of evidence, which never had a good reason for existence, surviving none the less through two centuries upon the strength of certain artificial dogmas pronouncement wholly reconcilable with each other, with the facts of life, and with the rule itself."

It is clear that marital privilege is an ancient monolith that South Africa has inherited from its colonial history and has to be reformed in order to find its place in a post-constitutional dispensation. This position is justified with the argument that the privilege exceeds its rationale, hampers the administration of justice by denying courts access to relevant information, and is at odds with the right to equality in terms of the Constitution. It is common cause that those in support of the privilege rely on the argument that marriage is sacrosanct and therefore is deserving of protection in order to preserve marital harmony. This therefore necessitates a robust approach to reform marital privilege, in order to achieve an equitable balance between ensuring the privilege is constitutionally sound and that people in unions still can confide in each other.

The study of foreign jurisdictions reveals that the privilege has its roots firmly entrenched in the law. The English legal regime is regarded as the primary source from which South Africa has derived its application of marital privilege. ${ }^{75}$ Both the English and American legal systems have,

72 Barton 45.

73 Barton 45.

74 Wigmore JH Evidence in Trials at Common Law (1961) 8.

75 Barton 45. 
through the years, produced extensive development in this area of the law. ${ }^{76}$ These countries have endorsed marital privilege through the common law and legislation.

This, however, cannot detract lawmakers from the fact that, in South Africa, there has been a social and political evolution which necessitates the development of the common law by interpreting the rules governing marital privilege more contextually, contemporarily, and constitutionally. South African legislators cannot absolve themselves of this responsibility. This does not however mean that South Africa should effect a complete abrogation of marital privilege - this is certainly not the ultimate solution. There are compelling arguments that suggest that such a privilege is of paramount importance in the preservation of a marital relationship. 77

Case law and academic commentaries reveal that this contentious area of law is embedded in our criminal justice system. Historical developments and comparative authorities referred to in this study suggest there are valid grounds for the reformation of marital privilege.

Naude $^{78}$ suggests three viable options. The first is that marital privilege should be abolished while still allowing the witness spouse the decision on whether to testify or not, with the exception being where the accused spouse has been charged with an offence listed in Section $195 .{ }^{79}$ This is an option that leaves the current position unchanged and therefore does not add much weight to the discussion on reforming the privilege.

It is recommended that privilege should be extended to include other categories of relationships that do not conform to the conventional notion of a marriage. ${ }^{80}$ These would include co-habitants as well as couples that have chosen not to enter into a marriage or cannot legally enter into a marriage. The difficulty in implementing such an extension arises with the task of defining such relationships. ${ }^{81}$ This would be arduous in that the courts would have to define relationships that function as a marriage. ${ }^{82}$ This would force the courts to go through a factual enquiry in order to assess the relationship. ${ }^{83}$ This would be based on questions such as the length of the relationship, whether the couple are living together, and their financial dependence on each other. ${ }^{84}$ In addition, the prosecution would face the laborious task of facing confrontation by countless couples who do not want to give evidence, until the court has pronounced on whether their relationship is afforded

$\begin{array}{ll}76 & \text { Lusty } 9 . \\ 77 & \text { Naude } 334 . \\ 78 & \text { Naude } 343 . \\ 79 & \text { Naude } 343 . \\ 80 & \text { Naude } 343 . \\ 81 & \text { Naude } 343 . \\ 82 & \text { Naude } 343 . \\ 83 & \text { Naude } 343 . \\ 84 & \text { Naude } 343 .\end{array}$


protection by the privilege. ${ }^{85}$ This would certainly place an enormous strain on the South African judicial system. It would also undermine criminal proceedings, which, as Naude points out, may not be the arena for the evaluation of relationships in terms of ascertaining their functionality as a marriage. ${ }^{86}$ Despite these points of criticism, it is submitted that in order to remedy the inequality that currently exists through the operation of the privilege - however difficult it may be for the courts to adapt this approach - is not impossible and will be required for the proper administration of justice.

The second recommendation is to render spouses the same as all other category of witnesses, and, in addition, as Naude suggests - allow the court the discretion to pardon spouses when it is not in the public interest that they be compelled to testify. ${ }^{87}$ This is the most flexible approach. It seeks to balance the interests of justice with the interests of society. ${ }^{88}$

The final recommendation is to remove marital privilege from South African law completely - thereby forcing spouses to be competent and compellable, and with no room for exception. ${ }^{89}$ This would remedy the situation where the privilege appears to be operating in conflict with the Constitution but would not do much for the protection of communications between couples.

It would also create equality among all categories of relationships and witnesses. However, it begs the question as to whether this may be the best solution. Naude argues this is an inflexible approach and is not desirable when one analyses the controversial nature of spousal testimony in the first place - in an area of the law where it is difficult to adopt a hard and fast approach. ${ }^{90}$ The authors support this view that the defects in the law surrounding marital privilege cannot be cured through a rigid approach. This would be difficult to enforce, without opposition from different sectors of society, and could raise many issues in a diverse country such as South Africa, where there are a wide array of societal norms and standards.

In order for the Constitution's values to be protected South African lawmakers must effect an amendment to the current provisions governing marital privilege. While the future of marital privilege in South African law may be shrouded in uncertainty, there is one thing we know for sure, and that is the constitutional right of equality before the law requires a re-consideration of marital privilege.

85 Naude 343

86 Naude 343.

87 Naude 344

88 Naude 344

89 Naude 344

90 Naude 344. 
